\title{
Rootstock Effects on Leaf Photosynthesis in 'Navelina' Trees Grown in Calcareous Soil
}

\author{
M. Carmen González-Mas', M. José Llosa, Antonio Quijano, \\ and M. Angeles Forner-Giner \\ Instituto Valenciano de Investigaciones Agrarias (IVIA), Centro de Citricultura \\ y Producción Vegetal, Carretera Moncada-Náquera Km. 4.5, 46113, Moncada, \\ Valencia, Spain
}

Additional index words. Carrizo citrange, rootstocks, calcareous soils tolerance, nonphotochemical quenching, photochemical quenching, photosynthesis

\begin{abstract}
Citrus crops in the Mediterranean region are often grown in high $\mathrm{pH}$ calcareous soils, which promote nutrient imbalances, especially iron deficiency. 'Navelina' trees grafted on eight different citrus rootstocks were assessed in terms of their relative tolerance to these soils. To do so, leaf gas exchange and chlorophyll $a$ fluorescence parameters were measured for 2 consecutive years in leaves without visible injury symptoms. Trees were grown on the rootstocks Carrizo citrange, hybrids of Cleopatra mandarin $\times$ Poncirus trifoliata no. 5 (F-A 5), 13 (F-A 13), and 16 (030116), Troyer citrange $\times$ common mandarin no. 18 (F-A 418), King mandarin $\times P$. trifoliata no. 7 (F-A 517), 020324 (Troyer citrange $\times$ Cleopatra mandarin), and Volkamer lemon $\times P$. trifoliata no. 64 (230164). $g_{S}$ and transpiration rate were clearly lower in leaves of shoots grafted on Carrizo citrange than in those on the other rootstocks assayed, but net photosynthetic flux did not differ. However, leaves of shoots on Carrizo citrange displayed a decline in their maximum quantum yield of PSII photochemistry [variable fluorescence/maximum fluorescence $\left(F_{v} / F_{m}\right)$ ratio] and other chlorophyll parameters in the steady state such as photochemical quenching $\left(q_{P}\right)$ and the quantum efficiency of PSII photochemistry $\left(\Phi_{\mathrm{PSII}}\right)$ as well as an increase in nonphotochemical quenching $\left(\mathrm{q}_{\mathrm{N}}\right)$. Other rootstocks such as 030116, F-A 517 and, especially, F-A 5 showed the highest $\Phi_{P S I I}$ and $F_{v} / F_{m}$ values, whereas F-A 5 had the lowest $\mathrm{q}_{\mathrm{N}}$ in the steady state. The photosynthetic characteristics observed in leaves on Carrizo citrange showed them to be the least tolerant to these calcareous conditions, whereas photosynthesis of 'Navelina' trees budded on F-A 5 were the most tolerant.
\end{abstract}

Citrus is the major fruit crop grown in the Mediterranean area, especially in the Valencia region in Spain, and is one of the most important fruit crops in the world. It is estimated that between $20 \%$ and $50 \%$ of fruit trees grown in the Mediterranean basin suffer from iron (Fe) deficiency (Jaegger et al., 2000). The most prevalent cause of Fe deficiency in this region is the presence of high levels of carbonate ions in calcareous soils, leading to a high $\mathrm{pH}$ and low availability of $\mathrm{Fe}$ and the condition known as lime-induced chlorosis (Pestana et al., 2005). The citrus trees planted in these soils often show signs of severe Fe deficiency or $\mathrm{Fe}$ chlorosis because of low $\mathrm{Fe}$ availability (Wallace, 1986). Iron deficiency

Received for publication 13 Aug. 2008. Accepted for publication 4 Jan. 2009.

This work has been supported through European Social Fund (FEDER).

We thank A. Calatayud for her advice during the writing of this article and E. Gorbe for helping with the statistical analysis. M.A. Forner-Giner and M.C. González were beneficiaries of a project awarded by the Generalitat Valenciana (GV05/217).

${ }^{1}$ To whom reprint requests should be addressed. e-mail gonzalez_mde@gva.es. affects the biochemistry, morphology, and physiology of the whole plant because $\mathrm{Fe}$ is an important cofactor of many enzymes, including those involved in the biosynthetic pathway of chlorophylls (Abadía, 1992; Larbi et al., 2006; Molassiotis et al., 2006).

In calcareous soils, citrus-growing success depends on availability of suitable rootstock that is tolerant of low Fe. Trifoliate orange [Poncirus trifoliata (L.) Raf.], sweet orange [C. sinensis (L.) Osb.], and Carrizo citrange (C. sinensis $\times P$. trifoliata) are all susceptible to lime-induced chlorosis, whereas sour orange $(C$. aurantium L.) and Cleopatra mandarin (C. reshni Hort. ex Tan.) are more limetolerant (Castle, 1987; Hamzé et al., 1986; Pestana et al., 2005; Treeby and Uren, 1993). Within this context, a breeding program is being carried out at the Instituto Valenciano de Investigaciones Agrarias (IVIA; Valencia, Spain) in the search for better-performing citrus rootstocks in alkaline soils. As a result of this program, four new hybrid rootstocks are now available in Spanish citrus nurseries: Forner-Alcaide 5 (F-A 5) and F-A 13 (both $C$. reshni Hort. ex Tan. $\times$ P. trifoliata), F-A 418 [Troyer citrange $(C$. sinensis $\times P$. trifoliata $) \times$ C. deliciosa Ten.], and F-A 517 (C. nobilis Lour. $\times P$. trifoliata). These rootstocks have been tested in calcareous soils. 'Navelina' trees grafted on F-A 5 or F-A 13 yielded $\approx 40 \%$ more than trees on Carrizo citrange, whereas trees on F-A 5 or F-A 13 produced smaller but similar quality fruit than those on Carrizo (Forner et al., 2003; Forner-Giner et al., 2003).

Evaluation of growth and yield parameters may not be sufficient to rank citrus rootstocks according to their tolerance to $\mathrm{Fe}$ chlorosis (Pestana et al., 2003, 2005). In this respect, physiological parameters like leaf chlorophyll, $\mathrm{CO}_{2}$ gas exchange, and chlorophyll $a$ fluorescence emission are known to be affected in leaves of trees that are not tolerant to $\mathrm{Fe}$ chlorosis or calcareous soils (Baveresco et al., 2006; Chouliaras et al., 2004; Larbi et al., 2006; Molassiotis et al., 2006; Morales et al., 2000)

The main objective of this study was to evaluate calcareous soil tolerance of 'Navelina' orange trees grafted on Carrizo citrange and seven new citrus rootstocks by assessing gas exchange and chlorophyll $a$ fluorescence.

\section{Materials and Methods}

Plant material. Measurements were taken for leaves of 13-year-old 'Navelina' orange trees, Citrus sinensis (L.) Osb. (selection Iniasel 7), grafted on Carrizo citrange and seven new citrus rootstocks obtained by $\mathrm{J}$. Forner at the IVIA: F-A 5, F-A 13, F-A 418, F-A 517, 030116 (Cleopatra mandarin $\times P$. trifoliata), 020324 (Troyer citrange $\times$ Cleopatra mandarin), and 230164 (C. volkameriana Ten. \& Pasq. $\times$ P. trifoliata). The trees were planted in 1993 with nursery plants (1 year after grafting) and arranged in a complete randomized experimental plot. There were six trees for each rootstock type in the plot. Tree spacing was $2.5 \times 6 \mathrm{~m}$. The soil was sandy loam with $40 \%$ of $\mathrm{CaCO}_{3}, 8 \%$ deactive calcium carbonate, and $\mathrm{pH} 8$. A relative level of carbonate between $5 \%$ and $10 \%$ is considered high. Standard cultural practices were followed with drip irrigation and fertilizing without iron chelates, mechanical weed control between rows, and chemical control between trees. Drip irrigation frequency was adjusted according to the season of the year, from once per week in winter to $5 \mathrm{~d}$ per week in summer, with $40 \mathrm{~L} /$ tree per irrigation. Water $\mathrm{pH}$ was 7.6, electrical conductivity $1.4 \mathrm{dS} \cdot \mathrm{m}^{-1}, \mathrm{Cl}^{-} 134.8 \mathrm{mg} \cdot \mathrm{L}^{-1}$, and $\mathrm{NO}_{3}{ }^{-}$ $158.0 \mathrm{mg} \cdot \mathrm{L}^{-1}$. Fertilization was applied from March to September in the following amounts: ammonium nitrate (33\%) $2 \mathrm{~kg} /$ tree, monoammonium phosphate $0.5 \mathrm{~kg} /$ tree, and potassium nitrate $0.8 \mathrm{~kg} /$ tree. During these months, the percentage distribution was 10 , $12,15,18,20,15$, and 10 for ammonium nitrate; $10,20,15,15,15,15$, and 10 for monoammonium phosphate; and 7, 10, 13, $15,25,20$, and 10 for potassium nitrate.

Gas exchange measurements. Measurements were taken at the end of October during 2 consecutive years (2005 to 2006) on eight expanded spring leaves for each rootstock type in the field. A portable gas exchange system (CIRAS-2; PP Systems, 
Hitchin, U.K.) was used with a PLC 6(U) universal leaf autocuvette in closed-circuit mode (Larbi et al., 2006). All measurements were taken on attached mature leaves that were $\approx 6$ months old without visible injury symptoms and with an apparent homogeneous green color. All measurements were performed at saturation irradiance (1000 $\left.\mu \mathrm{mol} \cdot \mathrm{m}^{-2} \cdot \mathrm{s}^{-1}\right)$ between $1030 \mathrm{HR}$ and 1130 $\mathrm{HR}$, whereas leaf temperature ranged between 24 and $26{ }^{\circ} \mathrm{C}$. The infrared method was used to determine leaf temperature. The gas exchange parameters determined at saturation irradiance were: transpiration rate $(E)$ $\left[\mathrm{mmol}\left(\mathrm{H}_{2} \mathrm{O}\right) \cdot \mathrm{m}^{-2} \cdot \mathrm{s}^{-1}\right]$, net photosynthetic flux $\left(\mathrm{P}_{\mathrm{n}}\right)\left[\mu \mathrm{mol}\left(\mathrm{CO}_{2}\right) \cdot \mathrm{m}^{-2} \cdot \mathrm{s}^{-1}\right], g_{\mathrm{S}}$ to water vapor $\left[\mathrm{mmol}\left(\mathrm{H}_{2} \mathrm{O}\right) \cdot \mathrm{m}^{-2} \cdot \mathrm{s}^{-1}\right]$, and $\mathrm{CO}_{2}$ substomatal concentration $\left(\mathrm{C}_{\mathrm{i}}\right)$ [ $\mu \mathrm{mol}\left(\mathrm{CO}_{2}\right) \cdot \mathrm{mol}^{-1}$ (air)]. The enclosed portion of the leaf was $2.50 \mathrm{~cm}^{2}$ and the cuvette flow was $200 \mathrm{~mL} / \mathrm{min}$. The ambient $\mathrm{CO}_{2}$ concentration was maintained at $375 \mathrm{ppm}$ and citrus leaves were chosen according to Larbi et al. (2006).

The environmental conditions during measurements were: temperature means, $24.1{ }^{\circ} \mathrm{C}$ (2005) and $24.9{ }^{\circ} \mathrm{C}$ (2006). Air relative humidity means were $65.8 \%$ (2005) and $64.2 \%$ (2006). No rainfall was recorded on the measurement days. These environmental conditions were similar on all measurement days.

Pigment analysis. The concentration of Chl per area was estimated in the same attached leaves as those for which gas exchange measurements were taken using a SPAD portable apparatus (Minolta Co., Osaka, Japan). Strong positive correlations between SPAD readings and chlorophyll concentration were found in leaves on all rootstocks $\left(r^{2}>\right.$ $0.8)$.

Chlorophyll a fluorescence measurements. Like in the case of gas exchange, chlorophyll $a$ fluorescence ( $\mathrm{Chl} \mathrm{F})$ was measured at ambient temperature $\left(24\right.$ to $26^{\circ} \mathrm{C}$ ) in the field during the same time period on 2 consecutive years using a portable fluorometer (PAM-2001; Walz, Effeltrich, Germany). The same eight spring flush leaves for each rootstock used for previous measurements (four leaves per year) were darkened for $30 \mathrm{~min}$ before fluorescence measurement. The minimum (dark) fluorescence $\left(F_{o}\right)$ was obtained after chlorophyll excitation with a weak beam from a lightemitting diode. Maximum fluorescence $\left(\mathrm{F}_{\mathrm{m}}\right)$ was determined following a $600-\mathrm{ms}$ pulse of saturating "white light." The yield of variable fluorescence $\left(F_{v}\right)$ was calculated as $F_{m}-F_{o}$. After 2 min of dark readaptation, actinic "white light" $\left(430 \mu \mathrm{mol} \cdot \mathrm{m}^{-2} \cdot \mathrm{s}^{-1}\right)$ was switched on and a saturating pulse $\left(14,000 \mu \mathrm{mol} \cdot \mathrm{m}^{-2} \cdot \mathrm{s}^{-1}\right)$ was applied at $60-\mathrm{s}$ intervals for $13 \mathrm{~min}$ to determine: 1) maximum fluorescence yield during actinic irradiation $\left.\left(\mathrm{F}_{\mathrm{m}}{ }^{\prime}\right) ; 2\right)$ the level of modulated fluorescence during a brief interruption of actinic irradiation in the presence of far-red radiation $\left(\mathrm{F}_{\mathrm{o}}{ }^{\prime}\right)$; and 3 ) the $\mathrm{Chl} F$ yield of fluorescence during the actinic illumination $\left(F_{t}\right)$. Quenching resulting from nonphotochemical dissipation of absorbed light energy $\left(\mathrm{q}_{\mathrm{N}}\right)$ was calculated at each saturating pulse according to the equation $\mathrm{q}_{\mathrm{N}}=\left(\mathrm{F}_{\mathrm{m}}-\right.$ $\left.\mathrm{F}_{\mathrm{m}}{ }^{\prime}\right) /\left(\mathrm{F}_{\mathrm{m}}-\mathrm{F}_{\mathrm{o}}{ }^{\prime}\right)$ (van Kooten and Snell, 1990).

Table 1. Total chlorophyll and gas exchange parameters of leaves from 'Navelina' trees grafted on eight rootstocks grown in calcareous soil. ${ }^{z}$

\begin{tabular}{|c|c|c|c|c|c|}
\hline Rootstocks & $\begin{array}{l}\text { SPAD } \\
\text { readings }^{\mathrm{y}}\end{array}$ & $\begin{array}{c}\mathrm{P}_{\mathrm{n}} \\
{\left[\mu \mathrm{mol}\left(\mathrm{CO}_{2}\right)\right.} \\
\left.\mathrm{m}^{-2} \cdot \mathrm{s}^{-1}\right]\end{array}$ & $\begin{array}{c}\mathrm{C}_{\mathrm{i}} \\
{\left[\mu \mathrm{mol}\left(\mathrm{CO}_{2}\right) .\right.} \\
\left.\mathrm{mol}^{-1}(\text { air })\right]\end{array}$ & $\begin{array}{c}\mathrm{g}_{\mathrm{s}} \\
{\left[\mathrm{mmol}^{-2}\left(\mathrm{H}_{2} \mathrm{O}\right)\right.} \\
\left.\mathrm{m}^{-2} \cdot \mathrm{s}^{-1}\right]\end{array}$ & $\begin{array}{c}\operatorname{EVAP}(E) \\
{\left[\mathrm{mmol}^{\left(\mathrm{H}_{2} \mathrm{O}\right)}\right.} \\
\left.\mathrm{m}^{-2} \cdot \mathrm{s}^{-1}\right]\end{array}$ \\
\hline F-A 5 & $65.3 \mathrm{a}$ & $10.6 \mathrm{a}$ & $487 \mathrm{~b}$ & $30 \mathrm{a}$ & $0.73 \mathrm{a}$ \\
\hline 030116 & $55.9 \mathrm{~b}$ & $7.0 \mathrm{abc}$ & $506 \mathrm{ab}$ & $27 \mathrm{a}$ & $0.72 \mathrm{a}$ \\
\hline F-A 517 & $56.3 \mathrm{~b}$ & $9.4 \mathrm{ab}$ & $369 \mathrm{c}$ & $27 \mathrm{a}$ & $0.68 \mathrm{a}$ \\
\hline F-A 13 & $57.9 \mathrm{ab}$ & $7.8 \mathrm{abc}$ & $449 \mathrm{bc}$ & $26 \mathrm{a}$ & $0.67 \mathrm{a}$ \\
\hline 020324 & $63.1 \mathrm{ab}$ & $7.2 a b c$ & $486 \mathrm{~b}$ & $30 \mathrm{a}$ & $0.68 \mathrm{a}$ \\
\hline 230164 & $41.4 \mathrm{c}$ & $5.3 \mathrm{c}$ & 599 a & $20 \mathrm{a}$ & $0.67 \mathrm{a}$ \\
\hline F-A 418 & $55.8 \mathrm{~b}$ & $7.4 \mathrm{abc}$ & $525 \mathrm{ab}$ & $29 \mathrm{a}$ & $0.77 \mathrm{a}$ \\
\hline \multicolumn{6}{|l|}{ Carrizo } \\
\hline citrange & $38.0 \mathrm{~d}$ & $6.3 \mathrm{bc}$ & $543 \mathrm{ab}$ & $6 \mathrm{~b}$ & $0.13 \mathrm{~b}$ \\
\hline
\end{tabular}

${ }^{\mathrm{z}}$ For each parameter, one-way analysis of variance was performed with rootstocks as the independent variable. Values represent means $(\mathrm{n}=8)$. Data from both years are pooled. Values in columns followed by the different letters are statistically different at $P<0.05$ (least significant difference test).

${ }^{y} \mathrm{SPAD}$ reading in the leaves to estimate the content of chlorophyll; $\mathrm{P}_{\mathrm{n}}=$ net photosynthetic flux; $\mathrm{C}_{\mathrm{i}}=\mathrm{CO}_{2}$ substomatal concentration; $\mathrm{g}_{\mathrm{s}}=g_{\mathrm{S}}$ to water vapor; $E=$ transpiration rate.

The coefficient for photochemical quenching, $\mathrm{q}_{\mathrm{P}}$, which represents the fraction of open PSII reaction centers, was calculated as $\left(\mathrm{F}_{\mathrm{m}}{ }^{\prime}-\mathrm{F}_{\mathrm{t}}\right) /$ $\left(\mathrm{F}_{\mathrm{m}}{ }^{\prime}-\mathrm{F}_{\mathrm{o}}{ }^{\prime}\right)$ (Schreiber et al., 1989). The quantum efficiency of PSII photochemistry, $\Phi_{\text {PSII }}$, closely associated with the quantum yield of noncyclic electron transport, was estimated from $\left(\mathrm{F}_{\mathrm{m}}{ }^{\prime}-\mathrm{F}_{\mathrm{t}}\right) / \mathrm{F}_{\mathrm{m}}{ }^{\prime}$ (Genty et al., 1989). The fraction of photons absorbed by PSII, which was not used in photochemistry or dissipated in the PSII antenna $(\% \mathrm{X})$, was estimated from $\left(\mathrm{F}_{\mathrm{v}}{ }^{\prime} / \mathrm{F}_{\mathrm{m}}{ }^{\prime}\right)\left(1-\mathrm{q}_{\mathrm{P}}\right) \times 100$ (Demmig-Adams et al., 1996).

Statistical analysis. Data collected in the 2 consecutive years were tested for significance using analysis of variance using time and rootstocks as independent variables (statistical significance, $P \leq 0.05$ ), but the time variable (year) did not account for a significant amount of variation. Means were compared using the least significant differences method at a 95\% confidence level. Statistical analyses were performed using StatGraphics Plus for Windows, Version 2.1 (Statistical Graphics, Englewood Cliffs, NJ).

\section{Results}

Leaf chlorophyll. The SPAD measurements were used as an equated estimate of leaf chlorophyll concentration, because there was a linear relationship between these two parameters $\left(r^{2}>0.8\right.$; Jifon et al., 2005). Leaves of shoots grafted on F-A 5, F-A 13, and 020324 had the highest Chl concentration. Leaves of shoots budded on 230164 and Carrizo citrange showed the lowest Chl concentration (Table 1).

Gas exchange measurements. The leaves of shoots grafted on F-A 5 had the highest net photosynthetic flux $\left(\mathrm{P}_{\mathrm{n}}\right)$, which differed significantly from leaves on 230164 and Carrizo citrange but not from those grafted on the other rootstocks (Table 1). Leaves of shoots budded on F-A 517 had the lowest $C_{i}$, whereas leaves of shoots grafted on the other rootstocks had significantly higher $C_{i}$ with the exception of leaves of shoots budded on F-A 13. $g_{\mathrm{S}}$ and transpiration $(E)$ were significantly lower in Carrizo citrange than in the other rootstocks.
Changes in chlorophyll a fluorescence parameters. Table 2 shows the Chl $a$ fluorescence of dark-adapted parameters for the 'Navelina' spring flush leaves. The maximum quantum yield of PSII photochemistry estimated using the $F_{v} / F_{m}$ ratio was the smallest in leaves on Carrizo citrange. The decline in this ratio was mostly the result of a decrease in the fluorescence parameter $F_{m}$, not of an increase in the minimum level of fluorescence, $\mathrm{F}_{\mathrm{o}}$. The higher $\mathrm{F}_{\mathrm{v}} / \mathrm{F}_{\mathrm{m}}$ values from leaves on F-A 5 and 030116 than on the other rootstocks was the result of an increase in $\mathrm{F}_{\mathrm{m}}$.

An apparently steady state was reached after $\approx 4$ min of actinic illumination for quantum yield $\left(\Phi_{\mathrm{PSII}}\right)$ of the PSII electron transport and the fraction of open PSII centers $\left(\mathrm{q}_{\mathrm{P}}\right)$ in leaves on all rootstocks (Fig. 1A-B). Two minutes into the kinetics study, the values of $\Phi_{\mathrm{PSII}}$ and $\mathrm{q}_{\mathrm{P}}$ for leaves on Carrizo citrange were the lowest. The steady state of the $\Phi_{\text {PSII }}$ value for leaves on Carrizo citrange was $\approx 27 \%$ lower than $\Phi_{\text {PSII }}$ value for leaves on F-A 5, 030116, and F-A 517.

Immediately after actinic irradiation, $\mathrm{q}_{\mathrm{N}}$ rose quickly and reached maximum values

Table 2. Changes in $F_{o}, F_{m}$, and $F_{v} / F_{m}$ at the steady state in dark-adapted leaves from 'Navelina' trees grafted on eight rootstocks grown in calcareous soil. $^{\mathrm{z}}$

\begin{tabular}{llll}
\hline Rootstocks & \multicolumn{1}{c}{$\mathrm{F}_{\mathrm{o}}$} & \multicolumn{1}{c}{$\mathrm{F}_{\mathrm{m}}$} & \multicolumn{1}{c}{$\mathrm{F}_{\mathrm{v}} / \mathrm{F}_{\mathrm{m}}$} \\
\hline F-A 5 & $0.214 \mathrm{abc}$ & $1.163 \mathrm{a}$ & $0.816 \mathrm{a}$ \\
030116 & $0.211 \mathrm{abc}$ & $1.162 \mathrm{a}$ & $0.816 \mathrm{a}$ \\
F-A 517 & $0.203 \mathrm{bc}$ & $1.082 \mathrm{ab}$ & $0.802 \mathrm{ab}$ \\
F-A 13 & $0.226 \mathrm{ab}$ & $0.962 \mathrm{bc}$ & $0.761 \mathrm{c}$ \\
020324 & $0.207 \mathrm{abc}$ & $1.059 \mathrm{bc}$ & $0.795 \mathrm{ab}$ \\
230164 & $0.232 \mathrm{a}$ & $0.981 \mathrm{bc}$ & $0.776 \mathrm{bc}$ \\
F-A 418 & $0.190 \mathrm{c}$ & $0.917 \mathrm{c}$ & $0.789 \mathrm{abc}$ \\
Carrizo & & & \\
\multicolumn{1}{c}{ citrange } & $0.218 \mathrm{ab}$ & $0.769 \mathrm{~d}$ & $0.720 \mathrm{~d}$ \\
\hline
\end{tabular}

${ }^{\mathrm{z}}$ For each parameter, one-way analysis of variance was performed with rootstocks as independent variable. Values represent means $(n=8)$. Values in columns followed by the different letters are statistically different at $P<0.05$ (least significant difference test).

$\mathrm{F}_{\mathrm{o}}=$ the minimum (dark) fluorescence; $\mathrm{F}_{\mathrm{m}}=$ the maximum fluorescence; $F_{v}=$ the yield of variable fluorescence $\left(\mathrm{F}_{\mathrm{m}}-\mathrm{F}_{\mathrm{o}}\right) ; \mathrm{F}_{\mathrm{v}} / \mathrm{F}_{\mathrm{m}}=$ the maximum quantum yield of PSII photochemistry. 

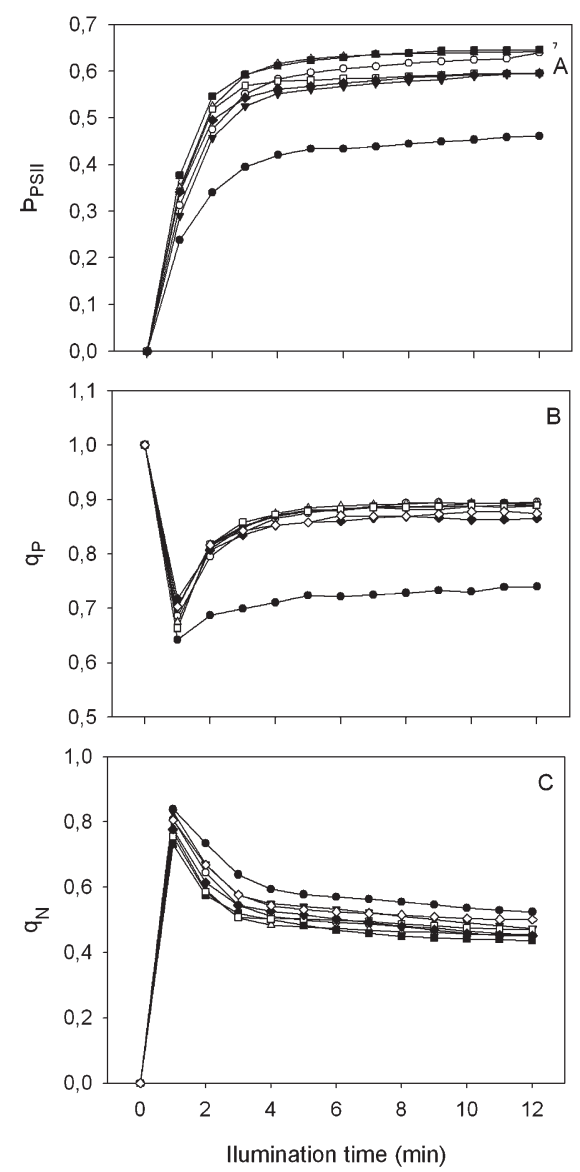

Fig. 1. Effects of rootstock on the kinetics of fluorescence parameters $\Phi_{\text {PSII }}$, the quantum efficiency of PSII photochemistry (A), $\mathrm{q}_{\mathrm{P}}$, photochemical quenching (B), and $\mathrm{q}_{\mathrm{N}}$, nonphotochemical quenching (C) of 'Navelina' trees grown in calcareous soil. Data are mean values and SD for $\mathrm{n}=8$. For all of measurements, SD of $\Phi_{\mathrm{PSII}}, \mathrm{q}_{\mathrm{P}}$, and $\mathrm{q}_{\mathrm{N}}$ was lower than $0.03,0.04$, and 0.02 , respectively. Symbols denote Carrizo citrange $(\bullet)$, F-A $517(\bigcirc)$, FA $13(\nabla), 030116(\triangle)$, F-A $5(\mathbb{\square}), 020324(\square)$, $230164(\diamond)$, and F-A $418(\diamond)$.

within 1 min (Fig. 1C). The maximum value was obtained for leaves of shoots grafted on Carrizo citrange. Nonphotochemical quenching declined until reaching steady-state values after $8 \mathrm{~min}$ of actinic irradiation with higher values for leaves on Carrizo citrange.

\section{Discussion}

In this article, we describe how rootstock affected the photosynthetic process in leaves from 'Navelina' trees grown on calcareous soil. In this respect, net photosynthetic values for leaves of shoots grafted on the eight different citrus rootstocks under study were similar to those reported in the literature (Calatayud et al., 2006; Syvertsen, 1987; $\mathrm{Vu}$ et al., 2002). Only leaves on F-A 5 rootstocks showed a higher $\mathrm{P}_{\mathrm{n}}$ rate than those on Carrizo citrange, whereas the intercellular $\mathrm{CO}_{2}$ concentration $\left(\mathrm{C}_{\mathrm{i}}\right)$ in leaves on Carrizo citrange was similar to the majority of other rootstocks. However, the $g_{\mathrm{s}}$ and the $E$ for leaves on Carrizo citrange were the lowest, as was chlorophyll content, when compared with the other citrus rootstocks assayed under the same conditions. Therefore, the lowest $g_{\mathrm{s}}$ and $E$ values for leaves of shoots grafted on Carrizo citrange did not decrease in $\mathrm{P}_{\mathrm{n}}$ or $\mathrm{C}_{\mathrm{i}}$. This can be explained by the fact that, as occurs under water stress, only very critically low levels of $g_{\mathrm{s}}$ affect $\mathrm{P}_{\mathrm{n}}$ and $\mathrm{C}_{\mathrm{i}}$, which is in agreement with Flexas et al. (2004).

On the other hand, although $P_{n}$ for leaves of shoots grafted on Carrizo citrange was not lower than for those grafted on the other rootstocks under study, fluorescence was impaired because leaves of shoots grafted on Carrizo citrange had a lower $\mathrm{F}_{\mathrm{m}}, \mathrm{F}_{\mathrm{v}} / \mathrm{F}_{\mathrm{m}}$ ratio, $\Phi_{\mathrm{PSII}}$, and $\mathrm{q}_{\mathrm{P}}$, but higher $\mathrm{q}_{\mathrm{N}}$ than those on the other rootstocks. The same behavior has been reported for Troyer citrange, in which the $F_{v} / F_{m}$ ratio decreased significantly with low Fe availability in calcareous soils (Pestana et al., 2005).

Maximum efficiency of photosystem II $\left(F_{v} / F_{m}\right)$ is only slightly affected by Fe deficiency in orange tree leaves (Pestana et al., 2001). However, we show that the variable part of the fluorescence was clearly affected by Carrizo citrange rootstocks on citrus trees grown on calcareous soils. The $\mathrm{F}_{\mathrm{v}} / \mathrm{F}_{\mathrm{m}}$ ratio was much lower in leaves of shoots grafted on this rootstock without changes in $F_{o}$ as compared with leaves on the other rootstocks, especially F-A 5 and 030116 , for which $\mathrm{F}_{\mathrm{v}} /$ $\mathrm{F}_{\mathrm{m}}$ values were the highest (Table 2). This decrease in the value of $F_{v} / F_{m}$ in Carrizo citrange was the result of a decrease in $F_{m}$ (maximum fluorescence yield in the darkadapted leaves), suggesting that the photochemistry of PSII was affected (Calatayud et al., 2004). By contrast, under the same conditions, $\mathrm{F}_{\mathrm{m}}$ leaves of shoots budded on $\mathrm{F}$ A 5 and on 030116 remained unaffected. Similar changes have been observed in $\mathrm{Fe}$ deficient leaves of peach and pear trees and grapevine (Baveresco et al., 2006; Morales et al., 2000; Nedunchezhian et al., 1997). Furthermore, 'Navelina' leaves of shoots grafted on Carrizo citrange displayed the lowest fraction of open PSII centers, $\mathrm{q}_{\mathrm{P}}$, in the steady state (Fig. 1B). This would indicate an incomplete reoxidation of the $\mathrm{Q}_{\mathrm{A}}$ acceptor and an increase in closed PSII centers during actinic irradiation (Calatayud et al., 2002). Leaves of shoots grafted on the other rootstocks had significantly higher $\mathrm{q}_{\mathrm{P}}$ values than on Carrizo citrange. The greater rate of closing of PSII centers in leaves on Carrizo citrange reduced the possibility of electron transport to photosystem I (Calatayud et al., 2004; Seaton and Walker, 1990). According to these $q_{P}$ values, efficiency of PSII centers $\left(\Phi_{\text {PSII }}\right)$ value in the steady state was lowest in leaves of shoots grafted on Carrizo citrange. In addition, the incomplete reoxidation of the $\mathrm{Q}_{\mathrm{A}}$ acceptor led to a greater fraction of reduced $\mathrm{Q}_{\mathrm{A}}$ in Carrizo citrange and, consequently, an increase in nonphotochemical quenching at the expense of photochemical use of excitation energy, as shown by our results for $\mathrm{q}_{\mathrm{N}}$ values. Leaves of shoots grafted on Carrizo citrange and F-A 418 showed the highest photoprotective $\mathrm{q}_{\mathrm{N}}$ in the steady state (Fig. 1C). 'Navelina' leaves of shoots budded on the other rootstocks presented $\mathrm{q}_{\mathrm{N}}$ values that were significantly minor to Carrizo citrange. The complementary study of the fraction neither used in photochemistry nor dissipated in the antennae $(\% \mathrm{X})$ showed that Carrizo citrange had the highest $\% \mathrm{X}$ as compared with the other rootstocks (data not shown). This fraction is the least desirable pathway because it may lead to oxidative damage (Calatayud et al., 2003; Demmig-Adams et al., 1996).

On the other hand, the study of nonphotochemical quenching $\left(\mathrm{q}_{\mathrm{N}}\right)$ during fluorescence kinetics showed that $\mathrm{q}_{\mathrm{N}}$ reached their maximum value within 1 min for leaves of shoots grafted on all rootstocks and leaves on Carrizo citrange had the highest $\mathrm{q}_{\mathrm{N}}$ value (Fig. 1C). Subsequently, $\mathrm{q}_{\mathrm{N}}$ values underwent a fast relaxation apart from Carrizo citrange, which had a slower ramp (Fig. 1C). This would be related to the fact that 'Navelina' leaves of shoots grafted on Carrizo citrange rootstocks grown in calcareous soil had lower stomatal opening and transpiration ( $g_{\mathrm{s}}$ and $E$ values) than those budded on all the other rootstocks. This limitation also correlated with a reduction in energy conversion efficiency of PSII $\left(\Phi_{\text {PSII }}\right)$ for Carrizo citrange during fluorescence kinetics, because its yield was significantly lower compared with the other rootstocks $2 \mathrm{~min}$ into the kinetics study (Fig. 1A). Moreover, the fraction of open PSII centers, $\mathrm{q}_{\mathrm{P}}$, decreased, reaching $\approx 70 \%$ for all rootstocks after the first saturation. However, this situation quickly reversed and all rootstocks recovered, reaching 90\% of open PSII centers in the following saturations, apart from Carrizo citrange, which could not surpass $73 \%$ (Fig. 1B). This could be the result of the incomplete reoxidation of $\mathrm{Q}_{\mathrm{A}}$, leading to the downregulation of photosynthesis in comparison with the other rootstocks under assay.

In conclusion, based on chlorophyll content, gas exchange, and the Chl $a$ fluorescence characteristics, trees grafted on F-A 5 performed best under these calcareous soil conditions, whereas those on Carrizo citrange were poorly adapted. Trees on the other six hybrid rootstocks performed well. These results are consistent with previous field evaluations on F-A 5 and F-A 13 rootstocks.

\section{Literature Cited}

Abadía, J. 1992. Leaf responses to Fe deficiency: A review. J. Plant Nutr. 15:1699-1713.

Baveresco, L., M. Bertamini, and F. Iacono. 2006. Lime-induced clorosis and physiological responses in grapevine (Vitis vinifera L. Cv. Pinot blanc) leaves. Vitis 45:45-46.

Calatayud, A., J.W. Alvarado, and E. Barreno. 2002. Differences in ozone sensitivity in three varieties of cabbage (Brassica oleracea L.) in the rural Mediterranean area. J. Plant Physiol. 159:863-868.

Calatayud, A., D.J. Iglesias, M. Talón, and E. Barreno. 2003. Effects of 2-month ozone exposure in spinach leaves on photosynthesis, antioxidant systems and lipid peroxidation. Plant Physiol. Biochem. 41:839-845. 
Calatayud, A., D.J. Iglesias, M. Talón, and E. Barreno. 2004. Response of spinach leaves (Spinacia oleracea L.) to ozone measured by gas exchange, chlorophyll $a$ fluorescence, antioxidant systems, and lipid peroxidation. Photosynthetica 42:23-29.

Calatayud, A., D.J. Iglesias, M. Talón, and E. Barreno. 2006. Effects of long-term ozone exposure on citrus: Chlorophyll $a$ fluorescence and gas exchange. Photosynthetica 44:548-554.

Castle, W.S. 1987. Citrus rootstocks, p. 361-369. In: Rom, R.C. and R.F. Carlson (eds.). Rootstocks for fruits crops. John Wiley and Sons, New York, NY.

Chouliaras, V., I. Therios, A. Molassiotis, A. Patakas, and G. Diamantidis. 2004. Effect of iron deficiency on gas exchange and catalase and peroxidase activity in citrus. J. Plant Nutr. 27:2085-2099.

Demmig-Adams, B., W.W. Adams, D.H. Barker, B.A. Logan, D.R. Bowling, and A.S. Verhoeven. 1996. Using chlorophyll fluorescence to assess the fraction of absorbed light allocated to thermal dissipation of excess excitation. Physiol. Plant. 98:253-264.

Flexas, J., J. Bota, J. Cifre, J.M. Escalona, J. Galmés, J. Gulías, E.-K. Lefi, S.F. MartínezCañellas, M.T. Moreno, M. Ribas-Carbó, D. Riera, B. Sampol, and H. Medrano. 2004. Understanding down-regulation of photosynthesis under water stress: Future prospects and searching for physiological tools for irrigation management. Ann. Appl. Biol. 144:273-283.

Forner, J.B., M.A. Forner-Giner, and A. Alcaide. 2003. Forner-Alcaide 5 and Forner-Alcaide 13: Two new citrus rootstocks released in Spain. HortScience 38:629-630.

Forner-Giner, M.A., A. Alcaide, E. Primo-Millo, and J.B. Forner. 2003. Performance of 'Navelina' orange on 14 rootstocks in northern Valencia (Spain). Sci. Hort. 98:223-232.
Genty, B., J.M. Briantais, and N.R. Baker. 1989. The relationship between the quantum yield of photosynthetic electron transport and quenching of chlorophyll fluorescence. Biochim. Biophys. Acta 990:87-98.

Hamzé, M., J. Ryan, and M. Zaabout. 1986 Screening of citrus rootstocks for lime-induced chlorosis tolerance. J. Plant Nutr. 9:459-469.

Jaegger, B., H. Goldbach, and K. Sommer. 2000. Release from lime induced iron chlorosis by CULTAN in fruit trees and its characterisation by analysis. Acta Hort. 531:107-113.

Jifon, J.L., J.P. Syvertsen, and E. Whaley. 2005 Growth environment and leaf anatomy affect nondestructive estimates of chlorophyll and nitrogen in Citrus sp. leaves. J. Amer. Soc. Hort. Sci. 130:152-158.

Larbi, A., A. Abadía, J. Abadía, and F. Morales. 2006. Down co-regulation of light absorption, photochemistry, and carboxylation in Fe-deficient plants growing in different environments. Photosynth. Res. 89:113-126.

Molassiotis, A., G. Tanou, G. Diamantidis, A Patakas, and I. Therios. 2006. Effects of 4month $\mathrm{Fe}$ deficiency exposure on Fe reduction mechanism, photosynthetic gas exchange, chlorophyll fluorescence and antioxidant defense in two peach rootstocks differing in Fe deficiency tolerance. J. Plant Physiol. 163:176-185.

Morales, F., R.L. Belkhodja, A. Abadía, and J. Abadía. 2000. Photosystem II efficiency and mechanism of energy dissipation in iron-deficient, field grown pear trees (Pyrus communis L.) Photosynth. Res. 63:9-21.

Nedunchezhian, N., F. Morales, A. Abadía, and J. Abadía. 1997. Decline in photosynthetic electron transport activity and changes in thylakoid protein pattern in field grown iron deficient peach (Prunus persica L.). Plant Sci. 129:2938.
Pestana, M., M. David, A. de Varennes, J. Abadía, and E. Araújo Faria. 2001. Responses of 'Newhall' orange trees to iron deficiency in hydroponics: Effects on leaf chlorophyll, photosynthetic efficiency, and root ferric chelate reductase activity. J. Plant Nutr. 24:1609-1620.

Pestana, M., A. de Varennes, J. Abadía, and E. Araújo Faria. 2005. Differential tolerance to iron deficiency of citrus rootstocks grown in nutrient solution. Sci. Hort. 104:25-36.

Pestana, M., A. de Varennes, and E. Araújo Faria. 2003. Diagnosis and correction of iron chlorosis in fruit trees: A review. Food. Agr. \& Environ. 1:46-51.

Schreiber, U., C. Neubauer, and C. Klughammer. 1989. Devices and methods for roomtemperature fluorescence analysis. Philos. Trans. R. Soc. Lond. Ser. B 323:241-251.

Seaton, G.G.R. and D.A. Walker. 1990. Chlorophyll fluorescence as a measure of photosynthetic carbon assimilation. Proc. R. Soc. Lond. B. Biol. Sci. 242:29-35.

Syvertsen, J.P. 1987. Nitrogen content and $\mathrm{CO}_{2}$ assimilation characteristics of Citrus Leaves. HortScience 22:289-291.

Treeby, M. and N. Uren. 1993. Iron deficiency stress responses amongst citrus rootstocks. Z. Pflanzenernahr 156:75-81.

van Kooten, O. and J.F.H. Snell. 1990. The use of chlorophyll fluorescence nomenclature in plant stress physiology. Photosynth. Res. 25:147150.

Vu, J.C.V., Y.C. Newman, L.H. Jr. Allen, M. GalloMeagher, and M. Zhang. 2002. Photosynthetic acclimation of young sweet orange trees to elevated growth $\mathrm{CO}_{2}$ and temperature. J. Plant Physiol. 159:147-157.

Wallace, A. 1986. Definition of stress in crop production-Iron plant nutrient and non-nutrient stress interaction. J. Plant Nutr. 9:187192. 